\title{
Kajian Penggunaan, Ketepatan, dan Biaya Antibiotik pada Pasien Rawat Inap Anak di Sebuah Rumah Sakit Umum di Surabaya
}

\author{
Silvia Monica ${ }^{1}$, Sylvi Irawati ${ }^{1,2}$, Eko Setiawan ${ }^{1,2}$ \\ ${ }^{1}$ Departemen Farmasi Klinis dan Komunitas, Fakultas Farmasi, Universitas Surabaya, \\ Surabaya, Indonesia, ${ }^{2}$ Pusat Informasi Obat dan Layanan Kefarmasian (PIOLK), \\ Fakultas Farmasi, Universitas Surabaya, Surabaya, Indonesia
}

\begin{abstract}
Abstrak
Ketepatan penggunaan antibiotik merupakan salah satu aspek penting untuk memastikan efektivitas dan keamanan terapi pada semua kelompok pasien, terutama kelompok pasien dengan perbedaan fisiologi dan profil farmakokinetika. Penelitian ini bertujuan untuk mengkaji penggunaan, ketepatan, dan biaya antibiotik pada bangsal rawat inap anak selama periode November-Desember 2015. Metode pengumpulan data pada penelitian ini adalah observasi yang dilakukan secara prospektif terhadap seluruh data rekam medis pasien rawat inap anak yang mendapatkan antibiotik selama periode pengambilan data. Data pasien rawat inap anak yang mendapatkan antibiotik dengan indikasi profilaksis sebelum pembedahan, menghendaki pulang paksa, dan memerlukan perawatan khusus pada saat pengambilan data dieksklusi dari penelitian. Total terdapat 109 rekam medis pasien yang memenuhi kriteria inklusi dan eksklusi. Sebesar 82 pasien $(75,23 \%)$ pada penelitian ini berusia $1-24$ bulan. Terdapat 5 pasien $(4,59 \%)$ dengan diagnosis keluar noninfeksi dan tidak memiliki tanda infeksi yang menerima antibiotik. Tidak terdapat pasien yang mendapatkan kultur bakteri. Golongan antibiotik yang paling banyak digunakan adalah sefalosporin generasi III yaitu sebesar 114 antibiotik (90,48\%), dan sebanyak 63 antibiotik $(55,26 \%)$ di antaranya adalah seftriakson. Penggunaan antibiotik pada 21 pasien $(45,65 \%)$ dinyatakan sesuai dosis, pada 19 pasien $(41,30 \%)$ hanya sesuai dosis dan frekuensi, serta pada 6 pasien diklasifikasikan sebagai tidak ada yang sesuai. Biaya rata-rata antibiotik per pasien pada penelitian ini adalah sebesar Rp209.731,72. Penggunaan antibiotik pada pasien rawat inap anak pada rumah sakit tempat pengambilan data perlu dioptimalkan ketepatannya. Kultur bakteri dan uji sensitivitas perlu diupayakan di rumah sakit tempat pengambilan data sebagai upaya penjaminan ketepatan antibiotik.
\end{abstract}

Kata kunci: Antibiotik, kajian penggunaan obat, pediatrik

\section{Review of the Utilization, Appropriateness, and Cost of Antibiotics among Paediatric Inpatients in a Public Hospital in Surabaya}

\begin{abstract}
An appropriate utilization of antibiotics is one of important aspects to assure treatment effectiveness and safety in all patient groups, especially in patients with distinctive physiology and pharmacokinetic profile. This study aimed to assess the utilization, appropriateness and cost of antibiotics administered in a pediatric hospital ward during November-December 2015. Method used to collect the data was observation conducted prospectively towards all medical records of paediatric inpatients receiving antibiotics during the study period. Medical records of patients receiving prophylaxis antibiotics before surgery, patients discharged against medical advice, and patients suddenly needed medical treatment in a special ward were excluded from the study. Overall, a total of 109 medical records met inclusion and exclusion criteria, in which $82(75.23 \%)$ patients' age ranged from 1 month to 2 years. There were $5(4.59 \%)$ patients with non-infectious diagnoses and no signs of infection receiving antibiotics. No patients were tested for a microbial culture. The most utilized antibiotic class was the $3^{\text {rd }}$ generation of cephalosporins (114 antibiotics, 90.48\%); $63(55.26 \%)$ of which was ceftriaxone. The utilization of antibiotics in $21(45.65 \%)$ patients was considered dose appropriate, in $19(41.30 \%)$ patients were dose-frequency appropriate and in 6 patients was classified as none appropriate. The mean of the cost of antibiotic per patient was IDR 209,731.72. There is a need to optimalize the appropriateness of antibiotic utilization in hospitalized pediatrics at the study hospital. Microbial culture and sensitivity tests would plausibly be one of preliminary steps to guard the appropriateness of antibiotic utilization.
\end{abstract}

Keywords: Antibiotics, drug utilization review, paediatrics

Korespondensi: Eko Setiawan, M.Sc., Apt., Fakultas Farmasi, Universitas Surabaya, Surabaya, Jawa Timur 60293, Indonesia,email: ekosetiawan.apt@gmail.com

Naskah diterima: 26 Februari 2018, Diterima untuk diterbitkan: 10 Agustus 2018, Diterbitkan: 1 September 2018 


\section{Pendahuluan}

Populasi anak merupakan salah satu komponen terbesar dalam menyusun piramida penduduk secara global. Di Indonesia, jumlah anak usia 0 sampai 4 tahun pada tahun 2013 adalah 71.708 .907 jiwa dari total 248.422.956 jiwa penduduk atau sebesar $28,87 \% .^{1}$ Besarnya populasi anak ini memunculkan tantangan dalam penyediaan layanan kesehatan yang mempertimbangkan kerentanan anak dalam mengalami gangguan kesehatan. Salah satu dari berbagai masalah kesehatan utama yang sering dialami oleh anak-anak adalah masalah terkait infeksi. Infeksi merupakan salah satu penyebab terbesar kematian pada anak-anak. Suatu penelitian menyatakan bahwa terdapat 6 sampai 7 juta kematian anak-anak usia di bawah 5 tahun pada tahun 2010 dan $64 \%$ di antaranya $(4,879$ juta jiwa) disebabkan oleh infeksi. ${ }^{2}$

Tingginya kasus infeksi pada anak-anak menyebabkan antibiotik sebagai salah satu obat yang sering diresepkan pada kelompok tersebut. Ironisnya, tidak jarang dijumpai pemakaian antibiotik yang tidak bertanggung jawab pada kelompok tersebut. ${ }^{3}$ Hasil analisis data National Ambulatory Medical Care Survey (NAMCS) dan National Hospital Ambulatory Medical Care Survey (NHAMCS) di United States pada tahun 2006-2008 menyebutkan terdapat $48,90 \%$ peresepan antibiotik untuk indikasi Acute Respiratory Tract Infection (ARTI) dan 23,40\% di antaranya merupakan pemberian antibiotik pada kondisi-kondisi yang sebenarnya tidak memerlukan antibiotik. ${ }^{3}$

Penggunaan antibiotik dengan cara tidak bertanggung jawab dapat memicu masalah yang merugikan, antara lain resistensi antimikroba, peningkatan biaya, dan timbulnya kejadian adverse drug reaction (ADR). Hasil penelitian pada kasus infeksi saluran kemih anak sepanjang tahun 2009-2012 di Rumah Sakit Anak di Iran menunjukkan bahwa 83,50\% isolat bakteri Eschericia coli telah resisten terhadap ampicillin dan $75,40 \%$ terhadap kotrimoksazol, meskipun kotrimoksazol adalah antibiotik empirik yang direkomendasikan sebagai terapi lini pertama untuk infeksi saluran kemih. ${ }^{4}$ Penelitian lain pada tahun 2004 di Iran menyatakan bahwa terdapat 65 ADR pada 36 dari total 300 pasien yang menggunakan antibiotik bersama dengan obat lain. ${ }^{5}$

Dengan mempertimbangkan besarnya penggunaan antibiotik pada kelompok anak dan adanya potensi kerugian yang diakibatkan penggunaan yang tidak bertanggung jawab, maka penelitian terkait analisis ketepatan penggunaan antibiotik pada kelompok anak seyogyanya perlu untuk dilakukan di Indonesia. Selain berdampak pada aspek klinis, ketepatan penggunaan antibiotik ini juga berdampak pada biaya pengobatan. Beban pembiayaan kesehatan akan semakin meningkat apabila kasus ketidaktepatan penggunaan antibiotik semakin banyak ditemukan. Besarnya beban pembiayaan tersebut dapat disebabkan oleh besarnya volume penggunaan antibiotik atau besarnya biaya yang dibutuhkan untuk mengatasi kasus infeksi oleh bakteri resisten akibat penggunaan antibiotik yang tidak bertanggung jawab. Sampai saat ini, belum banyak ditemukan penelitian tentang kajian pemakaian antibiotik pada anak di Indonesia. Tanpa didukung oleh data realita penggunaan antibiotik, upaya-upaya perbaikan peresepan antibiotik dapat menjadi tidak tepat sasaran dan jika hal ini dibiarkan bekelanjutan dapat meningkatkan biaya anggaran kesehatan di era implementasi Jaminan Kesehatan Nasional (JKN) di Indonesia. Tujuan utama penelitian ini adalah untuk melakukan analisis penggunaan, ketepatan, dan biaya penggunaan antibiotik pasien rawat inap anak di sebuah rumah sakit rujukan di Surabaya.

\section{Metode}

Penelitian ini merupakan penelitian deskriptif observasional yang dilakukan secara prospektif 
selama periode November-Desember tahun 2015 di sebuah rumah sakit rujukan di kota Surabaya. Bahan kajian dalam penelitian ini adalah data rekam medis pasien pada bangsal rawat inap anak, yaitu pasien usia 0-12 tahun yang menerima terapi antibiotik pertama kali pada bangsal rawat inap. Kriteria eksklusi dalam penelitian ini adalah data rekam medis milik pasien anak yang: (1) mendapatkan antibiotik dengan indikasi profilaksis sebelum pembedahan, (2) menghendaki pulang paksa, (3) pada saat pengambilan data secara tiba-tiba memerlukan perawatan khusus sehingga harus pindah dari bangsal rawat inap anak ke ruang rawat khusus lain, seperti Intensive Care Unit (ICU). Resep yang terdapat di bangsal tidak berupa lembar khusus melainkan permintaan tertulis melalui rekam medis. Observasi terkait pemberian antibiotik dilakukan untuk memperoleh data beyond use date (BUD) dan kompatibilitas. Penelitian dilakukan setelah mendapatkan izin pelaksanaan penelitian dari pihak rumah sakit melalui surat No. 070/147 09/436.7.8/2015.

Terdapat beberapa parameter yang diamati melalui data rekam medis pasien, yaitu: (1) karakteristik pasien, yang meliputi: usia, jenis kelamin, diagnosis, lama rawat inap, jumlah resep, jumlah obat per resep, berat badan, tinggi badan, suhu, leukosit, serta outcome klinis, (2) karakteristik obat, yang meliputi: jenis dan golongan, dosis, cara pemberian, rute pemberian, lama pemberian, jumlah pemberian, biaya, dan kesesuaian penggunaan, (3) karakteristik mikroorganisme, yaitu hasil kultur. Diagnosis pasien dibagi menjadi tiga bagian, antara lain: diagnosis masuk, diagnosis kerja, dan diagnosis keluar. Analisis BUD yang dilakukan pada penelitian ini dilakukan hanya pada sediaan intravena dengan melihat jangka waktu penyimpanan sisa sediaan setelah dibuka dari kemasan primer. Hasil analisis ini digolongkan dalam beberapa kelompok, yaitu: tidak sesuai dan sesuai. Pengelompokan tersebut dilakukan setelah melakukan analisis kondisi dan waktu penyimpanan aktual lalu dibandingkan dengan rekomendasi brosur sediaan.

Analisis kompatibilitas dan inkompatibilitas juga dilakukan hanya pada sediaan intravena dengan melakukan pengamatan terhadap pencampuran sediaan antibiotik dengan antibiotik lain, sediaan antibiotik dengan obat lain, dan sediaan antibiotik dengan pelarut. Hasil analisis kemudian digolongkan dalam beberapa kelompok, antara lain: kompatibel (K), inkompatibel (I), no information (NI), dan not applicable (NA). Pengelompokan tersebut didasarkan pada dua pustaka acuan, yaitu: Handbook on Injectable Drugs edisi 17 dan brosur sediaan antibiotik yang digunakan. Dengan mengacu pada buku referensi dan/ atau brosur tersebut, praktik pemberian dua atau lebih sediaan intravena dinyatakan: (1) kompatibel (K) jika dinyatakan secara jelas bahwa praktik pemberian campuran tersebut kompatibel, (2) inkompatibel (I) jika dapat disimpulkan dengan jelas bahwa praktik pemberian campuran tersebut inkompatibel, (3) no information (NI) jika tidak ditemukan informasi terkait profil kompatibilitas campuran tersebut, (4) tidak dapat disimpulkan atau not applicable (NA) apabila pada buku referensi dan/atau brosur tersebut terdapat perbedaan informasi yang bertolak belakang. Analisis lebih lanjut mengenai profil kompatibilitas dan inkompatibilitas berdasarkan tempat terjadinya dibedakan menjadi: larutan infus, syringe, dan Y-site.

Analisis kesesuaian penggunaan antibiotik hanya dilakukan pada pasien yang memiliki diagnosis masuk dan keluar terkait infeksi yang sama. Kesesuaian penggunaan antibiotik pada pasien dibandingkan dengan pedoman terapi Infectious Disease Society of America (IDSA) terbaru atau pedoman terapi lain yang sesuai jika tidak ditemukan pedoman terapi terbitan IDSA. Pedoman terapi lokal rumah sakit ini masih dalam tahap penyusunan pada saat penelitian ini berlangsung. Kesesuaian 
penggunaan antibiotik dianalisis secara lebih detail dengan berdasarkan kesesuaian pemilihan jenis, dosis, serta frekuensi dari pemberian antibiotik. Jenis antibiotik dikatakan tepat jika antibiotik yang diresepkan sesuai dengan rekomendasi pedoman terapi acuan. Dosis dikatakan tepat apabila dosis yang diberikan kepada pasien masih masuk dalam rentang $\pm 10 \%$ dengan dosis yang tertera pada pedoman terapi IDSA. Frekuensi dikatakan tepat jika frekuensi obat yang diberikan kepada pasien masih masuk dalam rentang $\pm 10 \%$ dengan frekuensi yang tertera pada pedoman terapi IDSA. Apabila tidak terdapat informasi pada pedoman terapi IDSA, maka buku Pediatric \& Neonatal Dosage Handbook edisi 20 tahun 2013 atau pedoman terapi lain yang sesuai digunakan sebagai dasar untuk melakukan analisis ketepatan jenis, dosis, dan frekuensi. Hasil analisis ketepatan tersebut kemudian diklasifikasikan lebih lanjut menjadi regimen terapi antibiotik tepat untuk seluruh terapi, tepat untuk sebagian terapi, dan seluruh regimen terapi antibiotik tidak sesuai.

Detail biaya yang dianalisis pada penelitian adalah sebagian dari direct medical cost yakni biaya yang diperlukan untuk mendapatkan antibiotik saja. Perspektif biaya disini adalah perspektif pasien, oleh karena itu data billing digunakan dalam penelitian ini. Penyesuaian harga dengan menggunakan laju inflasi tidak dilakukan dalam penelitian ini karena data diambil pada tahun yang sama dengan waktu pelaksanaan penelitian.

\section{Hasil}

Total terdapat 109 data rekam medis pasien anak yang memenuhi kriteria inklusi dan eksklusi penelitian selama periode November sampai dengan Desember tahun 2015. Tabel 1 memaparkan detail karakteristik pasien yang menggunakan antibiotik di rumah sakit tempat penelitian dilakukan selama periode November sampai dengan Desember 2015.
Tidak semua pasien memiliki diagnosis terkait infeksi, baik dalam diagnosis masuk maupun keluar. Sebanyak 75 pasien $(68,81 \%)$ dan 74 pasien $(67,89 \%)$ memiliki diagnosis masuk dan keluar terkait infeksi, secara berturutturut (Gambar 1). Pasien tanpa diagnosis terkait infeksi dapat atau tidak memiliki satu atau lebih tanda infeksi (Gambar 2). Tidak ada pasien yang mendapatkan kultur bakteri dalam penelitian ini.

Selama periode penelitian, terdapat sebanyak 108 pasien $(99,08 \%)$ yang mendapat antibiotik tunggal. Satu orang pasien anak mendapatkan kombinasi dari antibiotik seftriakson dengan kotrimoksazol. Golongan antibiotik yang paling banyak digunakan adalah golongan sefalosporin generasi III. Detail profil dari penggunaan antibiotik pada 109 pasien anak dijabarkan secara lebih terperinci pada Tabel 2. BUD tidak ditemukan pada penelitian ini, dikarenakan selama penelitian berlangsung, sediaan parenteral antibiotik langsung habis digunakan.

Total terdapat sebanyak 59 dari 109 pasien $(54,13 \%)$ dengan diagnosis masuk dan keluar yang tidak mengalami perubahan. Dari jumlah tersebut, total terdapat sebanyak 49 (44,95\%), $5(4,59 \%)$, dan 5 (4,59\%) pasien dari 59 pasien yang memiliki diagnosis Gastroenteritis Akut (GEA), bronkopneumonia, dan tifoid, secara berturut-turut. Regimen terapi antibiotik pada 59 pasien tersebut dapat tetap atau mengalami perubahan. Detail mengenai kesesuaian penggunaan antibiotik berdasarkan diagnosis masuk dan diagnosis keluar yang sama dan tidak mengalami perubahan regimen terapi antibiotik selama rawat inap, yaitu pada 44 pasien anak, dijelaskan secara lebih rinci pada Tabel 3. Terdapat 15 pasien $(13,76 \%)$ yang menerima perubahan regimen terapi selama menjalani rawat inap, dan detail kesesuaian penggunaan antibiotik pada pasien dengan perubahan antibiotik selama perawatan di rawat inap dijabarkan secara lebih terperinci pada Tabel 4. 
Tabel 1 Karakteristik Data Pasien Anak yang Mendapatkan Antibiotik Selama Menjalani Rawat Inap

\begin{tabular}{|c|c|c|}
\hline Karakteristik Pasien & Nilai/Jumlah & Persentase (\%) \\
\hline \multicolumn{3}{|l|}{ Jenis Kelamin } \\
\hline Laki-laki (pasien) & 60 & 55,05 \\
\hline Perempuan (pasien) & 49 & 44,95 \\
\hline Total & 109 & 100 \\
\hline \multicolumn{3}{|l|}{ Usia Pasien } \\
\hline Mean \pm SD (bulan) & $23,61 \pm 26,12$ & - \\
\hline Min-max (bulan) & $1-132$ & - \\
\hline \multicolumn{3}{|c|}{ Jumlah Partisipan yang Diklasifikasikan sebagai: } \\
\hline Newborn - 1 bulan (neonate) & 1 & 0,92 \\
\hline$>1$ bulan -24 bulan (infant) & 82 & 75,23 \\
\hline$>24$ bulan -12 tahun (children) & 26 & 23,85 \\
\hline \multicolumn{3}{|l|}{ Jumlah Partisipan yang: } \\
\hline Memiliki data berat badan & 55 & 50,46 \\
\hline Tidak memiliki data berat badan & $54 *$ & 49,54 \\
\hline \multicolumn{3}{|c|}{ Partisipan yang Memiliki Data Berat Badan: } \\
\hline Neonate & 1 & 1,82 \\
\hline Mean $\pm \mathrm{SD}(\mathrm{kg})$ & $5 \pm 0$ & - \\
\hline Infant & 40 & 72,73 \\
\hline Mean $\pm \mathrm{SD}(\mathrm{kg})$ & $8,60 \pm 2,07$ & - \\
\hline $\operatorname{Min}-\max (\mathrm{kg})$ & $5,8-15$ & - \\
\hline Children & 14 & 25,45 \\
\hline Mean $\pm \mathrm{SD}(\mathrm{kg})$ & $17,32 \pm 6,38$ & - \\
\hline $\operatorname{Min}-\max (\mathrm{kg})$ & $9-30$ & - \\
\hline \multicolumn{3}{|l|}{ Asal Pasien } \\
\hline IGD & 104 & 95,41 \\
\hline IRJ & 5 & 4,59 \\
\hline \multicolumn{3}{|l|}{ Lama Perawatan Pasien } \\
\hline Mean \pm SD (hari) & $5 \pm 2,09$ & - \\
\hline Min-max (hari) & $1-10$ & - \\
\hline \multicolumn{3}{|l|}{ Jumlah Resep } \\
\hline Mean \pm SD (lembar resep) & $4,17 \pm 1,68$ & - \\
\hline Min-max (lembar resep) & $1-9$ & - \\
\hline \multicolumn{3}{|l|}{ Hasil Terapi Pasien } \\
\hline Membaik & 107 & 98,17 \\
\hline Memburuk** $^{* *}$ & 2 & 1,83 \\
\hline Meninggal & 0 & 0 \\
\hline
\end{tabular}

\section{Keterangan:}

$\mathrm{SD}=$ standar deviasi, $M i n=$ minimum, $M a x=$ maksimum, IGD=Instalasi Gawat Darurat, IRJ=Instalasi Rawat Jalan.

Perhitungan persentase (\%) diperoleh dengan cara: jumlah pasien pada kelompok tertentu dibagi jumlah total pasien dikali 100. *Tidak tertera pada lembar IGD dan lembar status rawat inap anak; pasien yang tidak memiliki data berat badan maka berat badan diasumsikan sesuai dengan kurva pertumbuhan World Health Organization (WHO) untuk anak usia 0-5 tahun, sedangkan anak dengan usia di atas 5 tahun menggunakan formula dari National Health Service (NHS).

**Pasien dirujuk ke rumah sakit lain. 


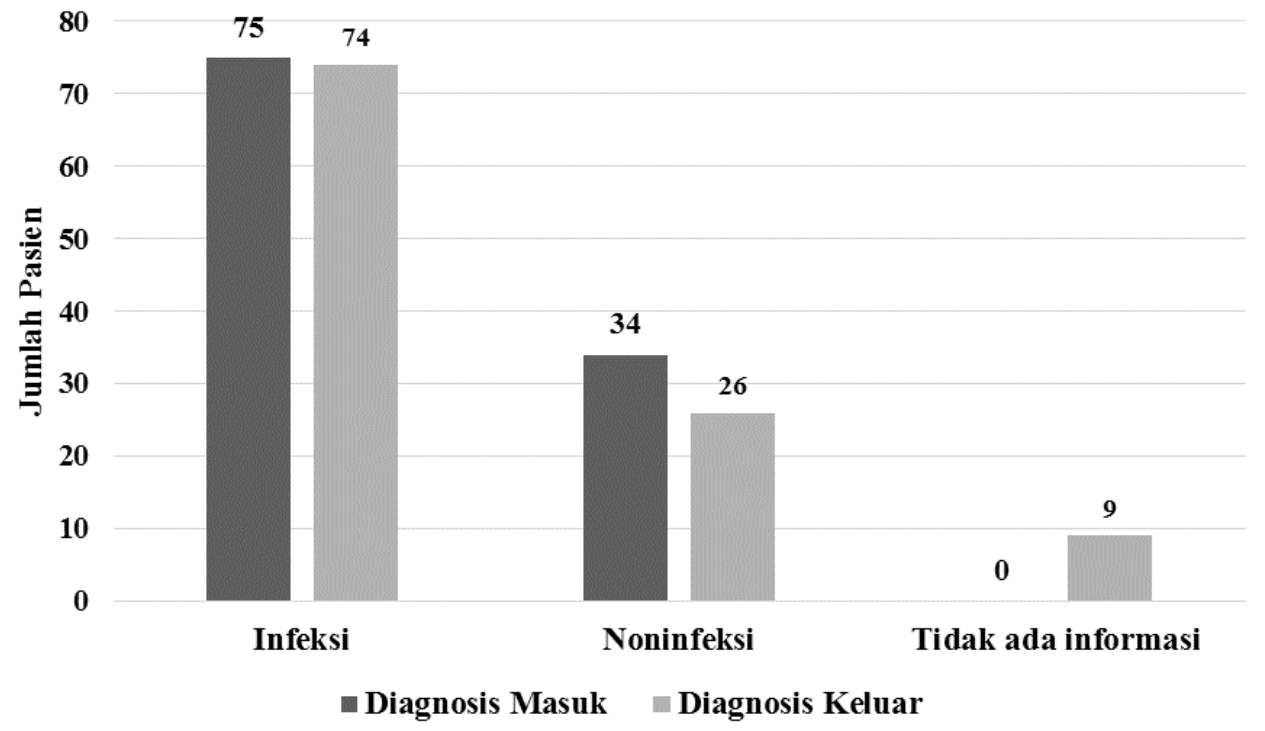

Gambar 1 Klasifikasi Diagnosis Pasien Anak yang Mendapatkan Terapi

Keterangan:

"Tidak ada informasi" menunjukkan kondisi diagnosis keluar yang tidak dituliskan pada lembar rekam medis pasien.

Seluruh antibiotik dengan rute pemberian intravena dilarutkan dengan pelarut aqua pro injection. Penggunaan $Y$-site dan syringe tidak ditemukan dalam penelitian ini. Dari beberapa sediaan antibiotik parenteral yang diberikan kepada pasien, terdapat satu jenis antibiotik

\section{Tanda Infeksi}

$$
12
$$

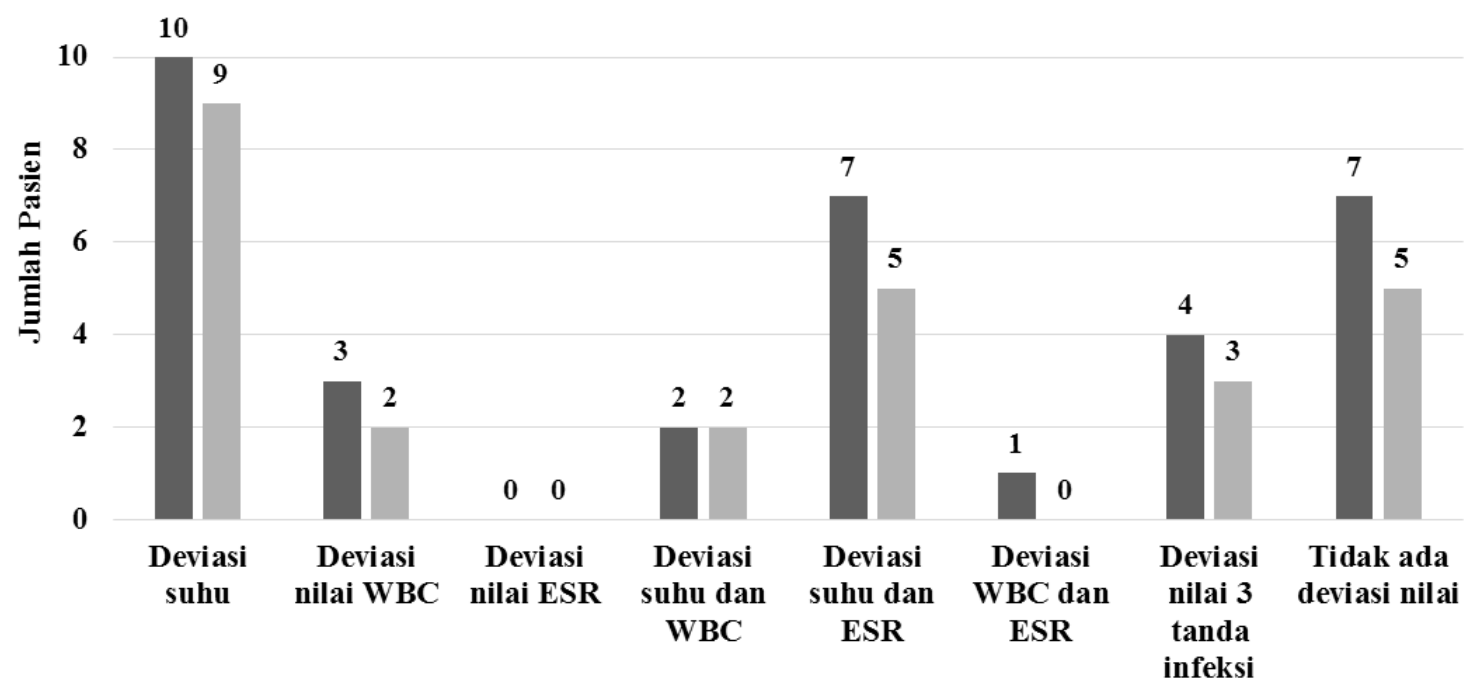

- Diagnosis Masuk Diagnosis Keluar

Gambar 2 Detail Informasi Terkait Tanda Infeksi pada Pasien dengan Diagnosis Masuk dan Keluar Noninfeksi Keterangan:

1. Deviasi nilai=nilai di luar rentang normal.

2. $\mathrm{WBC}=$ white blood cell; $\mathrm{ESR}=$ erythrocyte sedimentation rate .

3. Deviasi nilai 3 tanda infeksi: deviasi nilai suhu, WBC, dan ESR di luar rentang normal.

4. Tidak ada deviasi nilai: nilai suhu, WBC, dan ESR berada pada rentang normal. 
Tabel 2 Detail Profil Penggunaan Antibiotik

\begin{tabular}{|c|c|c|}
\hline Antibiotik & Nilai/Jumlah & Persentase $(\%)$ \\
\hline \multicolumn{3}{|l|}{ Penggunaan } \\
\hline Kombinasi (pasien) & 1 & 0,92 \\
\hline Tunggal (pasien) & 108 & 99,08 \\
\hline \multicolumn{3}{|c|}{ Golongan Antibiotik untuk Penggunaan Tunggal } \\
\hline Aminopenisilin & 2 & 1,59 \\
\hline Kombinasi penghambat enzim $\beta$-lactamase & 2 & 1,59 \\
\hline Sefalosporin generasi III & 114 & 90,47 \\
\hline Makrolid & 3 & 2,38 \\
\hline Folate antagonist & 5 & 3,97 \\
\hline \multicolumn{3}{|c|}{ Penggunaan Jenis Antibiotik Selama Menjalani Rawat Inap } \\
\hline Tetap (pasien) & 94 & 13,76 \\
\hline Berubah (pasien) & 15 & 86,24 \\
\hline \multicolumn{3}{|l|}{ Jenis Antibiotik } \\
\hline Amoksisilin & 2 & 1,59 \\
\hline Ampisilin sulbaktam & 2 & 1,59 \\
\hline Sefotaksim & 50 & 39,68 \\
\hline Sefoperazon sulbaktam & 1 & 0,79 \\
\hline Seftriakson & 63 & 50,00 \\
\hline Eritromisin & 3 & 2,38 \\
\hline Kotrimoksazol & 5 & 3,97 \\
\hline \multicolumn{3}{|l|}{ Dosis Antibiotik } \\
\hline Tetap & 102 & 80,95 \\
\hline Diganti & 24 & 19,05 \\
\hline \multicolumn{3}{|l|}{ Dosis Antibiotik } \\
\hline \multicolumn{3}{|l|}{ Amoksisilin } \\
\hline Mean $\pm \mathrm{SD}(\mathrm{mg})$ & $250 \pm 0$ & - \\
\hline \multicolumn{3}{|l|}{ Ampisilin sulbaktam } \\
\hline Mean \pm SD (mg) & $500 \pm 0$ & - \\
\hline \multicolumn{3}{|l|}{ Sefotaksim } \\
\hline Mean $\pm \mathrm{SD}(\mathrm{mg})$ & $268,10 \pm 96,74$ & - \\
\hline Min-max (mg) & $150-650$ & - \\
\hline \multicolumn{3}{|l|}{ Sefoperazon sulbaktam } \\
\hline Mean $\pm \mathrm{SD}(\mathrm{mg})$ & $250 \pm 0$ & - \\
\hline \multicolumn{3}{|l|}{ Seftriakson } \\
\hline Mean $\pm \mathrm{SD}(\mathrm{mg})$ & $338,13 \pm 153,23$ & - \\
\hline Min-max (mg) & $150-1000$ & - \\
\hline \multicolumn{3}{|l|}{ Eritromisin } \\
\hline Mean $\pm \mathrm{SD}(\mathrm{mg})$ & $283,33 \pm 28,87$ & - \\
\hline Min-max (mg) & $250-300$ & - \\
\hline \multicolumn{3}{|l|}{ Kotrimoksazol } \\
\hline Mean $\pm \mathrm{SD}$ & $131 \pm 94,50$ & - \\
\hline Min-max (mg) & $30-200$ & - \\
\hline \multicolumn{3}{|l|}{ Rute Pemberian } \\
\hline \multicolumn{3}{|l|}{ Intravena (IV) } \\
\hline IV bolus (pasien)* & 115 & 91,27 \\
\hline Infus (drip) intermittent (pasien)* & 1 & 0,79 \\
\hline Oral & 10 & 7,94 \\
\hline
\end{tabular}


Tabel 2 (Lanjutan) Detail Profil Penggunaan Antibiotik

\begin{tabular}{lcc}
\hline \multicolumn{1}{c}{ Antibiotik } & Nilai/Jumlah & Persentase (\%) \\
\hline Durasi atau Periode Waktu Pemberian & & - \\
Amoksisilin & & \\
Mean \pm SD (hari) & & - \\
Ampisilin sulbaktam & $5,5 \pm 2,12$ & - \\
Mean \pm SD (hari) & $4-7$ & - \\
Min-max (hari) & & - \\
Sefotaksim & $4,02 \pm 1,96$ & - \\
Mean \pm SD (hari) & $1-9$ & - \\
Min-max (hari) & 3 & - \\
Sefoperazon sulbaktam & & - \\
Seftriakson & $4,37 \pm 2,09$ & - \\
Mean \pm SD (hari) & $1-9$ & - \\
Min-max (hari) & & - \\
Eritromisin & $3 \pm 2$ & - \\
Mean \pm SD (hari) & $1-5$ & \\
Min-max (hari) & & \\
Kotrimoksazol & $1,8 \pm 1,30$ & \\
Mean \pm SD (hari) & $1-4$ & \\
Min-max (hari) & &
\end{tabular}

Keterangan:

$\mathrm{SD}=$ standar deviasi, $\mathrm{Min}=$ minimum, Max=maksimum.

*Menurut keterangan yang diberikan oleh perawat di bangsal rawat inap anak.

yang tidak ditemukan informasi mengenai ketercampuran dengan pelarutnya pada buku maupun brosur sediaan, yaitu sefotaksim. Oleh karena itu, kesesuaian campuran antara sefotaksim dengan pelarutnya dinyatakan no information.

Biaya rata-rata antibiotik untuk setiap pasien di rumah sakit tempat pengambilan

Tabel 3 Kesesuaian Penggunaan Antibiotik Berdasarkan Diagnosis Masuk dan Keluar yang Sama Tanpa Perubahan Regimen Terapi

\begin{tabular}{|c|c|c|c|}
\hline \multirow[b]{2}{*}{ Kriteria Kesesuaian } & \multicolumn{3}{|c|}{ Jumlah Pasien yang Sesuai (\%) } \\
\hline & $\begin{array}{c}\text { GEA } \\
(n=46)\end{array}$ & $\begin{array}{l}\text { Bronkopneumonia } \\
\qquad(\mathrm{n}=4)\end{array}$ & $\begin{array}{l}\text { Tifoid } \\
(n=5)\end{array}$ \\
\hline Dosis & $21(45,65)$ & 0 & 0 \\
\hline Frekuensi & 0 & 0 & 0 \\
\hline Pemilihan jenis antibiotik & 0 & 0 & $2(40,00)$ \\
\hline Dosis dan frekuensi & $19(41,30)$ & 0 & 0 \\
\hline Dosis dan pemilihan jenis antibiotik & 0 & 0 & 0 \\
\hline Frekuensi dan pemilihan jenis antibiotik & 0 & 0 & 0 \\
\hline Tidak ada yang sesuai* & $6(13,05)$ & 0 & 0 \\
\hline Sesuai semua kriteria** & 0 & $4(100)$ & $3(60,00)$ \\
\hline \multicolumn{4}{|c|}{$\begin{array}{l}\text { Keterangan: } \\
\text { * Yang dimaksud tidak ada yang sesuai adalah apabila dosis, frekuensi, dan pemilihan jenis antibiotik tidak sesuai dengan } \\
\text { pedoman terapi. }\end{array}$} \\
\hline
\end{tabular}


Tabel 4 Tabel Kesesuaian Penggunaan Antibiotik pada Pasien dengan Diagnosis Masuk dan Keluar yang Sama dengan Perubahan Regimen Terapi

\begin{tabular}{lccc}
\hline & Dosis & Frekuensi & Pemilihan Jenis Antibiotik \\
\hline GEA $(\mathrm{n}=3)$ & & & \\
Seluruh terapi sesuai & 0 & $1(33,33 \%)$ & $1(33,33 \%)$ \\
Sebagian terapi sesuai & $3(100,00 \%)$ & 0 & 0 \\
Seluruh terapi tidak sesuai & 0 & $2(66,67 \%)$ & $2(66,67 \%)$ \\
\hline
\end{tabular}

Keterangan:

1. GEA=gastroenteritis akut.

2. Yang dimaksud dengan seluruh terapi adalah dosis atau frekuensi atau pemilihan jenis antibiotik untuk semua regimen terapi telah sesuai penggunaannya selama pasien menjalani rawat inap.

3. Yang dimaksud dengan sebagian terapi adalah dosis atau frekuensi atau pemilihan jenis antibiotik tidak seluruhnya sesuai penggunaannya selama pasien menjalani rawat inap.

4. Pedoman terapi yang digunakan untuk melihat kesesuaian pada bronkopneumonia adalah IDSA, sedangkan pada GEA adalah PMK No. 5 tentang Panduan Praktik Klinis Dokter di Fasyankes Primer 2011.

data adalah sebesar Rp209.731,72/pasien/ perawatan $\pm \mathrm{Rp} 212.410,00$, dengan biaya terkecil adalah $\mathrm{Rp} 8.050,00$ dan biaya terbesar adalah Rp1.203.200,00. Biaya rata-rata untuk pasien dengan diagnosis non-infeksi lebih besar dibandingkan pasien dengan diagnosis infeksi (Tabel 5).

\section{Pembahasan}

Hasil penelitian ini menekankan bahwa masih terdapat kasus penggunaan antibiotik pada pasien dengan diagnosis noninfeksi. Hal tersebut dapat dijelaskan mengingat beberapa pasien pada penelitian ini (Gambar 2) memiliki gejala yang seringkali dipahami sebagai tanda terjadinya infeksi, antara lain: suhu tubuh $>38$ ${ }^{\circ} \mathrm{C}$, atau white blood cell (WBC) lebih tinggi dibandingkan nilai normal yang terdapat di laboratorium, atau erythrocyte sedimentation rate (ESR) lebih tinggi dibandingkan nilai normal. Akan tetapi, tanda dan gejala tersebut nyatanya tidak selalu mengindikasikan adanya infeksi yang disebabkan bakteri. ${ }^{6}$ Pemeriksaan kultur seyogyanya menjadi salah satu upaya untuk mengidentifikasi infeksi bakteri dan sekaligus menentukan jenis bakteri penyebab infeksi secara pasti. Namun, berdasarkan hasil penelitian ini, kultur bakteri juga tidak dilakukan di rumah sakit tempat pengambilan data. Terdapat banyak kemungkinan yang menjadi penyebab tidak dilakukannya kultur bakteri. Penelitian lebih lanjut perlu dilakukan untuk mengidentifikasi secara pasti kendala pelaksanaan kultur bakteri di rumah sakit tempat pengambilan data.

Masih dijumpainya penggunaan antibiotik yang tidak bertanggung jawab tidak hanya menjadi masalah di rumah sakit tempat dilakukannya penelitian ini. Sebuah penelitian yang dilakukan di sebuah rumah sakit anak di Botswana menyatakan bahwa dari total 93 pasien, terdapat 27 pasien dengan diagnosis noninfeksi dan 9 pasien di antaranya menerima

Tabel 5 Biaya Rata-Rata Pengobatan Antibiotik

\begin{tabular}{lcc}
\hline Keterangan & $\begin{array}{c}\text { Biaya Antibiotik untuk Pasien } \\
\text { dengan Diagnosis Infeksi* (Rp) }\end{array}$ & $\begin{array}{c}\text { Biaya Antibiotik untuk Pasien } \\
\text { dengan Diagnosis Noninfeksi** (Rp) }\end{array}$ \\
\hline Rata-rata & $191.580,90$ & $270.718,64$ \\
Minimal & $8.050,00$ & $8.050,00$ \\
Maksimal & $846.690,00$ & $1.203 .200,00$ \\
SD & $180.166,40$ & $297.550,88$ \\
\hline
\end{tabular}

Keterangan: $\mathrm{SD}=$ Standard Deviasi. Biaya dianalisis dengan satuan /pasien/perawatan.

*Biaya untuk 84 pasien dengan diagnosis masuk dan/atau keluar terkait infeksi.

**Biaya untuk 25 pasien dengan diagnosis masuk dan keluar noninfeksi. 
antibiotik. ${ }^{7}$ Penggunaan antibiotik pada pasien yang tidak memiliki diagnosis infeksi serta tanda-tanda infeksi perlu diminimalkan dan bahkan jika perlu dihindari, karena hal ini dapat berdampak pada peningkatan potensi resistensi pada antibiotik dan biaya yang harus dikeluarkan, khususnya pada era Jaminan Kesehatan Nasional (JKN) yang diterapkan mulai tahun 2014 di Indonesia.

Golongan antibiotik yang paling banyak digunakan dalam penelitian ini yaitu golongan sefalosporin generasi III, yakni sebanyak 114 antibiotik (90,48\%). Sefalosporin generasi III merupakan antibiotik dengan spektrum luas yang pada umumnya digunakan sebagai terapi empirik di sebagian besar kasus antibiotik. Pada penelitian ini, jenis antibiotik sefalosporin generasi III yang paling banyak digunakan adalah seftriakson yaitu sebesar 63 antibiotik $(55,26 \%)$. Penggunaan sefalosporin generasi III dalam jumlah yang cukup banyak juga ditemukan pada penelitian lain terkait kajian penggunaan antibiotik pada pasien rawat inap anak. ${ }^{8}$ Penggunaan seftriakson pada pasien anak seharusnya dihindari karena antibiotik ini memiliki protein binding yang besar yaitu 85-90\%, sehingga penggunaan seftriakson pada anak berpotensi menggeser bilirubin dari sisi ikatan dengan protein. ${ }^{9}$ Pemantauan kadar bilirubin pada anak yang mendapatkan seftriakson perlu dilakukan secara berkala untuk mencegah terjadinya peningkatan kadar bilirubin secara signifikan.

Selain mempunyai risiko terjadinya efek samping, penggunaan sefalosporin generasi III juga memiliki risiko terjadinya suprainfeksi, yaitu infeksi oleh Clostridium difficile yang memiliki gejala diare, serta memicu terjadinya strain bakteri yang resisten terhadap beberapa jenis antibiotik (multiple drug resistance, MDR). ${ }^{10}$ Sebuah penelitian yang dilakukan di England menyatakan, angka kejadian infeksi oleh Clostridium difficile setiap 1.000 defined daily dose (DDD) penggunaan sefalosporin generasi III adalah sebesar 5.2 (95\% CI 4.5-
5.9).${ }^{11}$ Dengan mempertimbangkan data tersebut, sudah seyogyanya penggunaan sefalosporin generasi III hanya dibatasi pada kasus infeksi yang benar-benar membutuhkan antibiotik tersebut.

Pemakaian sefalosporin generasi III yang tidak bertanggung jawab dapat menyebabkan terjadinya suatu resistensi melalui mekanisme pembentukan Extended Spectrum Beta Lactamase (ESBL). Hasil analisis dengan menggunakan metode analisis multivariat dari penelitian yang dilakukan oleh Muro, et al. (2012) menunjukkan bahwa penggunaan golongan sefalosporin dengan spektrum luas, termasuk sefalosporin generasi III, merupakan suatu faktor risiko yang signifikan yang dapat memicu terjadinya infeksi disebabkan oleh bakteri penghasil ESBL (OR 3.52; 95\% CI $1.0-12.23 ; \mathrm{p}=0.047) .{ }^{12}$ Apabila telah terbentuk mekanisme resistensi terhadap sefalosporin generasi III, maka pilihan antibiotik yang dapat digunakan untuk mengobati pasien menjadi lebih sedikit, dan pada umumnya, antibiotik pilihan tersebut memiliki harga yang lebih mahal, salah satunya golongan karbapenem.

Pada penelitian ini, diagnosis masuk dan diagnosis keluar yang paling banyak ditegakkan adalah GEA, yaitu sebesar 52 dan 48 pasien, secara berturut-turut. Tingginya kasus GEA di rumah sakit tempat pengambilan data juga selaras dengan yang ditemukan pada suatu penelitian di rumah sakit di Mahrashtra, India, yakni sebanyak $0,68-3,41 \%$ pasien anak yang menjalani rawat inap dan memiliki diagnosis GEA, dan $43,60 \%$ di antaranya merupakan pasien dengan usia kurang dari 5 tahun. ${ }^{13}$ Penggunaan antibiotik pada pasien GEA tidak selalu tepat dengan pertimbangan penyebab utama GEA tidak selalu bakteri. Sebagian besar GEA disebabkan oleh virus, yaitu sebesar hampir $40 \% .{ }^{14}$ Berdasarkan penelitian di sebuah rumah sakit di Denpasar, diperoleh bahwa dari $11,30 \%$ anak menjalani rawat inap karena diare (sebagai salah satu gejala GEA), sebesar $49,80 \%$ disebabkan oleh rotavirus. ${ }^{15}$ 
Sebuah pedoman terapi yang digunakan pada suatu rumah sakit anak di Cincinnati, United States, tidak merekomendasikan penggunaan antibiotik pada GEA yang terjadi pada anak. ${ }^{16}$ Oleh karena itu, sangat penting dilakukan pemeriksaan lebih lanjut untuk mengetahui penyebab pasti dari GEA seperti melakukan kultur bakteri. Penelitian lebih lanjut untuk mengetahui penyebab pasti dari GEA di rumah sakit tempat pengambilan data perlu dilakukan untuk melihat prevalensi penyebab GEA sehingga dapat diambil kebijakan terkait penggunaan antibiotik pada kasus GEA pada anak.

Berdasarkan hasil penelitian ini, tidak terdapat satu pun kesesuaian pemberian jenis antibiotik yang ditemukan. Pada penelitian ini, antibiotik yang digunakan pada pasien GEA adalah seftriakson, yaitu sebanyak 27 antibiotik $(58,71 \%)$. Pedoman terapi yang diterbitkan oleh European Society for Pediatric Infectious Diseases menyebutkan bahwa pemberian antimikroba kepada pasien GEA anak dapat dilakukan ketika penyebab pastinya telah teridentifikasi. ${ }^{17}$ Pada sebagian besar kasus GEA dengan kondisi pasien yang relatif sehat, pemberian antibiotik tidak direkomendasikan. Tidak dilakukan proses identifikasi penyebab GEA pada penelitian ini, oleh sebab itu dapat dikatakan pemberian antibiotik pada pasien dengan diagnosis GEA tidak sesuai dengan pedoman terapi.

Analisis tentang kesesuaian penggunaan antibiotik pada pasien dengan diagnosis GEA menunjukkan terdapat 21 pasien $(45,65 \%)$ yang termasuk kategori hanya sesuai terkait dosis, 19 pasien $(41,30 \%)$ hanya sesuai dosis dan frekuensi, serta 6 pasien diklasifikasikan sebagai tidak ada yang sesuai. Rata-rata dosis seftriakson yang digunakan pada pasien GEA dalam penelitian ini yaitu $65,65 \pm 21,40 \mathrm{mg} /$ $\mathrm{kg} \mathrm{BB} /$ hari dengan rentang dosis maksimum dan dosis minimum adalah $41,10-150 \mathrm{mg} / \mathrm{kg}$ BB/hari. Berdasarkan Pediatric and Neonatal Dosage Handbook edisi ke-20 (2013), banyak dosis seftriakson yang direkomendasikan adalah sebanyak $50-75 \mathrm{mg} / \mathrm{kg} \mathrm{BB} /$ hari sekali sehari. ${ }^{9}$ Apabila dilihat dari dosis rata-rata seftriakson, maka dapat disimpukan secara umum bahwa dosis seftriakson telah sesuai dengan pedoman.

Walaupun demikian, pada penelitian ini masih terdapat pasien yang mendapat dosis underdose dan overdose. Dosis antibiotik yang tergolong ke dalam underdose berpotensi menyebabkan konsentrasi antibiotik yang terdapat dalam tubuh berada di bawah kadar antibiotik yang dibutuhkan untuk menghambat pertumbuhan bakteri (minimum inhibitory concentration, MIC), sehingga aktivitas dari antibiotik tersebut tidak bisa maksimal yang dapat berpotensi menimbulkan resistensi. Berdasarkan frekuensi pemberiannya, pasien anak dalam penelitian ini mendapatkan seftriakson sebanyak 3 kali sehari, sedangkan pada buku Pediatric and Neonatal Dosage Handbook edisi ke-20, pemakaian seftriakson dianjurkan hanya 1 kali per hari. ${ }^{9}$ Frekuensi dan dosis pemberian suatu antibiotik perlu dipastikan ketepatannya, karena hal ini sangat memengaruhi keberhasilan dalam mencapai target farmakokinetik dan farmakodinamik. ${ }^{18}$ Bukti penelitian terpublikasi menunjukkan bahwa salah satu penentu keberhasilan terapi ialah ketercapaian target farmakokinetik dan farmakodinamik. ${ }^{19}$

Terdapat 5 pasien dengan diagnosis masuk dan keluar yang sama yaitu bronkopneumonia. Pemberian terapi antibiotik di dalam kasus pneumonia anak tidak selalu tepat dengan pertimbangan banyaknya kasus pneumonia yang disebabkan oleh virus. Lebih dari $70 \%$ pneumonia pada anak dengan usia $\leq 2$ tahun disebabkan oleh virus. ${ }^{20}$ Pernyataan tersebut didukung oleh penelitian yang dilakukan oleh Harris et al. pada anak, dengan Community Acquired Pneumoniae (CAP) di Amerika. yang membuktikan bahwa terdapat sebanyak 30-67\% kasus CAP yang disebabkan oleh virus, dan sebesar $77 \%$ dan $59 \%$ di antaranya 
terjadi pada anak usia $<1$ tahun dan $>2$ tahun secara berturut-turut. ${ }^{21}$ Sampai saat ini, bukti penelitian terpublikasi mengenai penyebab dari pneumonia anak di Indonesia belum ditemukan. Penelitian lebih lanjut mengenai mikroorganisme penyebab pneumonia pada pasien anak sangat diperlukan sebagai upaya mendukung gerakan penggunaan antibiotik yang bertanggung jawab di rumah sakit tempat pengambilan data.

Pada penelitian ini terdapat 4 orang pasien pneumonia $(80 \%)$ yang mendapat antibiotik tunggal yaitu seftriakson. Berdasarkan panduan terapi IDSA, seftriakson dapat digunakan untuk kasus infeksi yang disebabkan oleh bakteri Streptococcus pneumoniae, Streptococcus pneumoniae yang resisten terhadap penicillin, Streptococcus grup A, dan Haemophilus influenzae. ${ }^{22}$ Sebagian besar kasus CAP pada anak disebabkan oleh bakteri Streptococcus pneumonia dan Haemophilus influenzae. ${ }^{23}$ Secara praktis, penggunaan seftriakson pada penelitian ini dapat mengeradikasi bakteri penyebab CAP. Namun demikian, dengan mempertimbangkan banyaknya kasus CAP anak oleh virus, juga besarnya konsekuensi negatif penggunaan seftriakson sebagai salah satu jenis antibiotik golongan sefalosporin generasi III, praktik penggunaan seftriakson sebagai terapi lini pertama pada kasus CAP anak tidak direkomendasikan. Penggunaan amoksisilin yang efektif pada bakteri penyebab CAP dapat dianjurkan sebagai pengganti seftriakson.

Dari total 4 jenis antibiotik yang diberikan secara parenteral dalam penelitian ini, 3 di antaranya kompatibel dengan pelarutnya yaitu aqua pro injection. Tidak terdapat data mengenai kompatibilitas dan inkompatibilitas sefotaksim pada brosur dan buku. Dengan kata lain, pada penelitian ini masih dijumpai pencampuran sediaan intravena yang tidak diketahui profil kompatibilitasnya dengan pelarut yang digunakan. Hasil temuan penelitian ini juga ditemukan pada penelitian lain. Pada hasil penelitian yang dilakukan oleh Dwijayanti pada tahun 2015, terdapat obat yang tidak memiliki informasi mengenai ketercampuran antara senyawa obat dengan pelarutnya pada pasien dewasa dan anak sebesar 19,80\% dan $30,16 \% .{ }^{24}$ Pencampuran sefotaksim dengan pelarutnya perlu monitoring lebih lanjut untuk memastikan stabilitas sediaan dan efektivitas pengobatan. Penelitian lebih lanjut mengenai stabilitas pencampuran sefotaksim dengan pelarutnya perlu dilakukan sebagai upaya untuk memastikan keamanan pencampuran tersebut.

Hasil analisis biaya penggunaan antibiotik menunjukkan rata-rata biaya antibiotik pada pasien anak dengan diagnosis noninfeksi lebih besar dibandingkan pasien yang terdiagnosis infeksi. Alokasi anggaran tersebut tidak dapat dikatakan salah sepenuhnya, dengan mempertimbangkan beberapa pasien yang memiliki diagnosis noninfeksi menunjukkan tanda-tanda infeksi. Walaupun tidak selalu mengindikasikan infeksi bakteri, pada praktik setiap hari, tenaga kesehatan di rumah sakit tidak ingin mengambil risiko mempertaruhkan keselamatan pasien jika antibiotik tidak segera diberikan. Selain hal tersebut, perlu dipahami bahwa permasalahan pengobatan yang tidak tepat disebabkan oleh multifaktor yang perlu diselesaikan secara holistik sesuai dengan konteks lokal. ${ }^{25}$ Identifikasi masalah dan kebutuhan penunjang bagi tenaga kesehatan dengan tujuan untuk meningkatkan ketepatan penggunaan antibiotik sangat perlu dilakukan sebagai suatu upaya pencegahan kesalahan serupa dilakukan kembali di masa yang akan datang. Sejauh ini tidak ditemukan penelitian kajian biaya yang memaparkan secara umum besaran biaya penggunaan antibiotik untuk diagnosis infeksi dan noninfeksi pada anak. Terdapat dua penelitian cost-effectiveness yang membandingkan dua antibiotik untuk jenis penyakit infeksi tertentu saja pada pasien anak. Dengan demikian, hasil kajian ekonomi dua penelitian tersebut tidak dapat dibandingkan 
dengan hasil penelitian ini. ${ }^{26,27}$

Salah satu keterbatasan terkait biaya pada penelitian ini adalah hasil analisis biaya yang tidak merepresentasikan keseluruhan direct medical cost pasien rawat inap anak karena pengamatan hanya dilakukan pada data biaya antibiotik. Selain itu, hasil analisis biaya tidak dapat dibandingkan dengan biaya pada pasien rawat inap anak dari rumah sakit lain karena sumber data biaya yang digunakan pada penelitian ini adalah billing pasien yang lebih merepresentasikan besar charge rumah sakit kepada pasien dibandingkan dengan besar real cost per pasien. Sangat mungkin bahwa besarnya charge, termasuk untuk antibiotik, dapat berbeda antar rumah sakit. Oleh karena itu, penelitian lebih lanjut mengenai analisis direct medical cost pasien rawat inap anak dengan menggunakan perspektif rumah sakit atau payers dapat dilakukan sebagai gambaran utuh besarnya biaya perawatan infeksi pada pasien rawat inap anak.

\section{Simpulan}

Penggunaan antibiotik terbanyak untuk pasien rawat inap pada penelitian ini adalah golongan sefalosporin generasi III. Masih ditemukan pasien anak dengan diagnosis noninfeksi yang mendapatkan terapi antibiotik, bahkan beberapa di antaranya tidak memiliki tanda infeksi sama sekali. Biaya antibiotik rata-rata untuk pasien dengan diagnosis noninfeksi lebih besar bila dibandingkan pasien dengan diagnosis infeksi pada penelitian ini, yakni sebesar Rp270.718,64 dan Rp191.580,90, secara berturut-turut. Tidak banyak pasien yang mendapatkan terapi antibiotik yang tepat untuk 3 jenis kriteria penilaian ketepatan, yakni tepat jenis, dosis, frekuensi pemberian. Adanya pasien dengan diagnosis noninfeksi dan belum optimalnya ketepatan pemberian antibiotik berdasarkan pedoman terapi klinis menjadi tanda perlunya koordinasi antarpihak di rumah sakit.

\section{Pendanaan}

Penelitian ini tidak didanai oleh sumber hibah manapun.

\section{Konflik Kepentingan}

Peneliti menyatakan tidak terdapat konflik kepentingan apapun pada penelitian ini.

\section{Daftar Pustaka}

1. Ministry of Health, Republic of Indonesia. Indonesia health profile 2013. [Accessed on: 16 January 2016]. Available from: http:// www.depkes.go.id/resources/download/ pusdatin/profil-kesehatan-indonesia/pro fil-kesehatan-indonesia-2013.pdf.

2. Liu L, Johnson HL, Cousens S, Perin J, Scott S, Lawn JE, et al. Global, regional, and national causes of child mortality: an updated systematic analysis for 2010 with time trends since 2000. Lancet. 2012; 379(9832):2151-61. doi: 10.1016/S0140 $-6736(12) 60560-1$.

3. Hersh AL, Shapiro DJ, Pavia AT, Shah SS. Antibiotic prescribing in ambulatory pediatrics in the United States. Pediatrics. 2011;128(6):1053-61. doi: 10.1542/peds. 2011-1337.

4. Mirsoleymani SR, Salimi M, Shareghi Brojeni M, Ranjbar M, Mehtarpoor M. Bacterial pathogens and antimicrobial resistance patterns in pediatric urinary tract infections: A four-year surveillance study (2009-2012). Int J Pediatr. 2014; 2014:126142. doi: 10.1155/2014/126142.

5. Khotaei GT, Fattahi F, Pourpak Z, Moinfar Z, Aghaee FM, Gholami K, et al. Adverse reactions to antibiotics in hospitalized Iranian children. J Microbiol Immunol Infect. 2008; 41(2):160-4.

6. Chow A, Robinson JL. Fever of unknown origin in children: A systematic review. World J Pediatr. 2011;7(1):5-10. doi: 10. 
1007/s12519-011-0240-5

7. Fisher BT, Meaney PA, Shah SS, Irwin SA, Grady CA, Kurup S, et al. Antibiotic use in pediatric patients admitted to a referral hospital in Botswana. Am J Trop Med Hyg. 2009;81(1):129-31. doi: 10.4269/ajtmh.2 009.81 .129

8. Sharma M, Damlin A, Pathak A, Lundborg CS. Antibiotic prescribing among pediatric inpatients with potential infections in two private sector hospitals in Central India. PLoS One. 2015;10(11):e0142317. doi: 10.1371/journal.pone.014231

9. Takemoto CK, Hodding JH, Kraus, DM. Pediatric \& Neonatal Dosage Handbook, $20^{\text {th }}$ Ed. Ohio: Lexi-Comp, Inc; 2013.

10. Gallagher J, MacDougall C. Antibiotics simplified. $2^{\text {nd }}$ Ed. United States: David Cella; 2012.

11. Pereira JB, Farragher TM, Tully MP, Jonathan Cooke J. Association between Clostridium difficile infection and antimicrobial usage in a large group of English hospitals. Br J Clin Pharmacol. 2013;77(5):896-903. doi: 10.1111/bcp. 12255

12. Muro S, Garza-González E, CamachoOrtiz A, González GM, Llaca-Díaz JM, Bosques F, et al. Risk factors associated with extended-spectrum $\beta$-lactamaseproducing Enterobacteriaceae nosocomial bloodstream infections in a tertiary care hospital: A clinical and molecular analysis. Chemotherapy. 2012;58(3):217-24. doi: 10.1159/000339483.

13. Ujwala U, Shekhar R, Ganesh L, Sandeep S, Nanda T, Kumar R. Seasonal patterns in acute gastroenteritis in a hospital at Maharashtra, India. Int J Health Sci Res. 2012;1(2):101 -8.

14. So CW, Kim DS, Yu ST, Cho JH, Kim JD. Acute viral gastroenteritis in children hospitalized in Iksan, Korea during December 2010-June 2011. Korean J Pediatr. 2013; 56(9):383-8. doi: 10.3345/kjp.2013.56.9. 383
15. Salim H, Karyana IP, Sanjaya-Putra IG, Budiarsa S, Soenarto Y. Risk factors of rotavirus diarrhea in hospitalized children in Sanglah Hospital, Denpasar: A prospective cohort study. BMC Gastroenterol. 2014;14: 54. doi: 10.1186/1471-230X-14-54

16. Anderson JM. Evidence-based care guideline: Prevention and management of acute gastroenteritis (AGE) in children aged 2 months to 18 years. [Accessed on: 16 January 2016]. Available from: http://www.g-i-n.net/library/healthtopics-collection/guidelines/ahrq-us/ evidence-based-care-guideline-forprevention-and-management-of-acutegastroenteritis-age-in-children-aged2-months-to-18-years.-cincinnatichildrens-hospital-medical-center.ngc-008846.

17. Guarino A, Ashkenazi S, Gendrel D, Lo Vecchio A, Shamir R, Szajewska $\mathrm{H}$; European Society for Pediatric Gastroenterology, Hepatology, and Nutrition; European Society for Pediatric Infectious Diseases. European Society for Pediatric Gastroenterology, Hepatology, and Nutrition/ European Society for Pediatric Infectious Diseases evidence-based guidelines for the management of acute gastroenteritis in children in Europe: Update 2014. J Pediatr Gastroenterol Nutr. 2014;59(1):132 -52. doi: 10.1097/MPG.00000000000003 75.

18. Asín-Prieto E, Rodríguez-Gascón A, Isla A. Applications of the pharmacokinetic/ pharmacodynamic (PK/PD) analysis of antimicrobial agents. J Infect Chemother. 2015;21(5):319-29. doi: 10.1016/j.jiac.2 015.02 .001 .

19. Onufrak NJ, Forrest A, Gonzalez D. Pharmacokinetic and pharmacodynamic principles of anti-infective dosing. Clin Ther. 2016;38(9):1930-47. doi: 10.1016/j .clinthera.2016.06.015.

20. Ali A, Akhund T, Warraich GJ, Aziz F, 
Rahman N, Umrani FA, et al. Respiratory viruses associated with severe pneumonia in children under 2 years old in a rural community in Pakistan. J Med Virol. 2016; 88(11):1882-90. doi: 10.1002/jmv.24557.

21. Harris M, Clark J, Coote N, Fletcher P, Harnden A, McKean M, et al. British Thoracic Society guidelines for the management of community acquired pneumonia in children: Update 2011. Thorax. 2011;66(2):ii1-23. doi: 10.1136/thoraxjnl-2011-200598

22. Bradley JS, Byington CL, Shah SS, Alverson B, Carter ER, Harrison C, et al. The management of community-acquired pneumonia in infants and children older than 3 months of age: Clinical practice guidelines by the Pediatric Infectious Diseases Society and the Infectious Diseases Society of America. Clin Infect Dis. 2011; 53(7):e25-76. doi: 10.1093/cid/cir531.

23. Das A, Patgiri SJ, Saikia L, Dowerah P, Nath R. Bacterial pathogens associated with community-acquired pneumonia in children aged below five years. Indian Pediatr. 2016;53(3):225-7. doi: 10.1007/s13312-
016-0825-0

24. Dwijayanti S, Irawati S, Setiawan E. Compatibility profile of intravenous medications among intensive care unit patients. Indones J Clin Pharm. 2016;5(2): 84-97. doi: 10.15416/ijcp.2016.5.2.84

25. Ofori-Asenso R, Agyeman AA. Irrational use of medicines - A summary of key concepts. Pharmacy (Basel). 2016;4(4):35. doi: 10.3390/pharmacy4040035

26. Rosyid A, Timur WW, Nafirin A. Cost effectiveness analysis treatment of typhoid fever used chloramphenicol and cefixime antibiotics in children (observation study analytical of Islamic Hospital Sultan Agung Semarang period from January to December 2015. Media Farmasi Indonesia. 2017;12(2):1248-58.

27. Beatrix KMJ, Citraningtyas G, Sudewi S. Analisis efektivitas biaya pengobatan pasien pediatric demam tifoid menggunakan cefixime dan cefotaxime di RSU Pancaran Kasih GMIM Manado. Pharmacon. 2018; $7(2): 17-27$.

(C) 2018 Monica et al. The full terms of this license incorporate the Creative Common Attribution-Non Commercial License (https://creative commons.org/licenses/by-nc/4.0/). By accessing the work you hereby accept the terms. Non-commercial use of the work are permitted without any further permission, provided the work is properly attributed. 